\title{
Intertextuality, Rhetorical History and the Uses of the Past in Organizational Transition
}

Maclean, M., Harvey, C., Sillince, J.A.A. \& Golant, B.D. (2018). Intertextuality, Rhetorical History and the Uses of the Past in Organizational Transition. Organization Studies, accepted and forthcoming.

\begin{abstract}
This paper draws upon archival and oral history research on organizational transition at Procter \& Gamble (1950-2009), during which P\&G evolved from a multinational to global enterprise. Intertextuality, the ways in which texts appropriate prior works to produce new texts, illuminates the practical workings of rhetorical history, accentuating interpretive agency. The uses of the past at $P \& G$ involved an authorized historical account relating to socialization, invented tradition, and lessons from past experience, facilitating change within continuity. We show that in transforming from multinational to global enterprise, recognition of the value of history to strategy intensified, engendering rhetorically intense variations on time-honoured themes. Our main contribution to theory is to demonstrate how sensitivity to intertextuality casts light on the nature of organizational history as historically constructed through language, subject to the agency of skilful interpretive actors who engage in intertextual adaptation in pursuit of strategic change as purposes and contexts evolve.
\end{abstract}

\section{Keywords}

Historical organization studies, intertextuality, narrative, organizational history, rhetorical history, strategic change.

\section{Introduction}

It is increasingly recognized that perceptions of history in organizations are socially

constructed. How organizations are made sense of in historical time helps to determine how they are experienced in everyday life, setting expectations for the present and future (Suddaby, Foster \& Quinn-Trank, 2010b). This paper builds upon archival and oral history research on organizational transition at Procter \& Gamble (P\&G) from 1950 to 2009. As a long-established company founded in 1837 that exhibits a strong interest in its history, $\mathrm{P} \& \mathrm{G}$ offers fertile terrain for exploring the uses of the past in organizations and organizing. Here, we offer a historically informed theoretical narrative that draws on executives' speeches, annual reports and interviews with $P \& G$ managers in the manner of 'historical organization studies' (Maclean, Harvey \& Clegg, 2016; 2017). This entails organizational research to which history is integral, drawing extensively on historical data, methods and knowledge to 
blend historical narrative with organizational analysis; promoting 'dual integrity' so that history and organization studies are recognized as being of equal status.

Examining the company's documentary record over a 60-year period affords the potential to highlight reinterpretations of meaning over time, alerting to moments of organizational transition or disjuncture as well as the maintenance of company values. Intertextuality is an interdisciplinary term borrowed from modern linguistics and literary theory that acknowledges the fundamental interdependence of texts, emphasizing that texts draw their substantial meaning from previous texts (Kristeva, 1986; Saussure, 1974). We define intertextuality as the numerous ways in which texts appropriate prior works, which they adapt and rework in response to new contexts, remaining open to interpretation and alteration in subsequent retelling. This suggests that texts derive much of their sense from their precursors, which authors recontextualize to create something similar yet different, attentive to new situations. In this way, 'meaning becomes something which exists between a text and all other texts to which it relates, moving out from the independent text into a network of textual relations' (Allen, 2011: 1).

According to Barthes (1977: 159), the word 'text' implies 'a tissue, a woven fabric' contained in language. Here, we use the term to denote primarily documents and the transcripts of speeches captured in archives, including oral histories which typically draw on collective memories. Texts may also be transmitted verbally, so messages may be heard as well as written and/or read; although according to Boje (2008: 86) textuality trumps orality in formal organizations, perhaps because it leaves enduring traces. Texts are situated in contexts on which they draw for meaning, influenced by the Zeitgeist of the period in which they were produced. Hence, a corporate archive preserves for posterity a collection of records gathered by an organization that bear witness to its past. As such it represents a powerful resource, conducive to manipulation and interpretive agency. This has implications for 
intertemporality, which concerns the linkages between past, present and future conditions and occurrences, promoting knowledge transfer over time, transcending temporal demarcations (Braudel, 1980; Garud and Nayyar, 1994). Adopting Barthes' analogy, what we call here the $\mathrm{P} \& \mathrm{G}$ 'intertext', the body of texts that comprises the company's history thus far, resembles 'a tapestry of multiple interacting, interpenetrating collective memories' (Boje, 2008: 81). This looks forward while drawing inspiration from the past; its main objective being to generate a blended but evolving discourse through which executives adapt aspects of the company's authorized account, repurposed to reflect shifts in internal circumstances and external contexts.

In this paper we address two guiding research questions. First, what are the primary uses to which past has been deployed at $P \& G$ over its history? Second, if we take seriously the notion that an organization's history is a resource that may be exploited intertextually, what role has intertextuality played in the social construction and evolution of the $P \& G$ narrative during its transition from multinational to global enterprise? Our paper proceeds as follows. The next section reviews the literature on historical narrative in the emergent field of historical organization studies, focusing on the role of intertextuality within rhetorical accounts. We then provide details of the research on which the study is founded, explaining our research process, data sources and analytical methods. In our empirical section, we probe the documentary record to examine the various uses of the past deployed at P\&G. Finally, we discuss our findings, consider the implications for the theory and practice of the uses of history in organizations and organizing, and reflect on the limitations of our study and avenues for further research.

\section{Intertextuality and Rhetorical History}

Intertextuality, a concept familiar to discourse analysts yet little used as yet by organization theorists, acknowledges that the individual author of a text is an assembler of remnants, 
constructing an order from assorted shards of the past (Porter, 1986). Texts refer directly or indirectly to previous texts and depend on them for their meaning. Organizational archives and archivists promote intertextuality by facilitating the interaction between current executives and the situations they confront with the wealth of documents stored from the past. Hence, studying archival documents intertextually implies searching for relevant vestiges and connections. Acknowledging a need for continuity, texts respond to audience expectations by featuring familiar words and concepts, with implications for the construction of social identity and collective memory (Halbwachs, 1992; Jenkins, 2014).

Intertextuality facilitates the recycling of prior texts, and calls into question the individual authorship of an account, which may involve an interchange between multiple authors (Barthes, 1977), as texts are interpreted and altered in subsequent retelling. This presents archival texts in a new light as potentially compiled by participants who form ‘intertextual chains', reducing temporal distances (Fairclough, 1992: 288). It implies a form of distributed agency as successive authors rework an organizational narrative in response to new contexts, internal and external (Garud \& Karnoe, 2002). In containing prior texts, reworked texts imply 'the insertion of history... into a text and of this text into history' (Kristeva, 1986: 39). Skilful use of the documentary record enables the organization's history to emerge as a narrative characterized by dynamic repetition while inducing a sense of shared interaction among organizational members (Suddaby, Foster \& Quinn-Trank, 2016).

The words that comprise texts are not incidental, according to Saussure (1974), because our understanding of reality derives from the social use of verbal signs. Saussure explains that verbal signs draw their signification from the historically constructed texts within which they are situated. However, our understanding of social reality rests on collections of texts, since the meaning of a text is not located within an isolated text but within a dialogue or network of texts to which it relates (Phillips, Lawrence \& Hardy, 2004). 
Since words are always tokens for something else, the study of semiotics is inextricably bound up with values (Barthes, 1957; Li, 2017). Texts mirror the cultural conditions that obtain at their point of writing, just as organizations exude the values prevalent at their time of operation (Suddaby, Elsbach, Greenwood, Meyer \& Zilber, 2010a). Studying texts over time may therefore reveal parallel changes in the values of the broader cultural environments in which an organization's history is embedded and evolves. This emphasizes the importance of situating companies and their practices within the wider socio-political contexts or 'sociopasts' in which they arose (Durepos, 2015; Durepos \& Mills, 2012).

It is understandable that a long-established organization endowed with a rich history might view this as a potent competitive resource to be exploited. Suddaby et al. (2010b) affirm the importance of a company's history as a potentially valuable, rare, inimitable and malleable resource that organizational actors can use to confer meaning upon the company's past in ways designed to shape opinion and influence action. What the authors call rhetorical history is thus 'the strategic use of the past as a persuasive strategy to manage key stakeholders' (Suddaby et al., 2010b: 157). Their work testifies to a new cognizance of the intentional use by managers of an organization's history to direct its ongoing and future strategy. Organizational actors can strategically mobilize historical narrative to promote or eliminate specific choices (Foster, Coraiola, Suddaby, Kroezen \& Chandler, 2016). This redirects attention towards a historically informed narrative perspective of strategy that is retrospective yet future-oriented, according to which actors 'create a discourse of direction (whether about becoming, being, or having been) to understand and influence one another's actions' (Barry \& Elmes, 1997: 432). Prior research has shown that organizational remembering goes hand-in-hand with its corollary, forgetting (Anteby \& Molnár, 2012; Casey \& Olivera, 2011). Considered thus, the past is not immutable but amenable to interpretive agency whereby managers subjectively re-interpret or edit the company's 
objective history to determine what should be remembered and what should be discarded to advance preferred outcomes (de Certeau, 1988; Li, 2017).

The work of Douglas Holt is relevant in this regard. Holt (2004) draws on Barthes (1957) to articulate how some organizations enact cultural strategies in ways that leverage specific mythologies and ideologies that echo macro-level discourses prevalent in wider society (Maclean, Harvey, Suddaby \& O’Gorman, 2017). He explains how distiller Jack Daniel's drew on the enduring power of the American frontier myth to reinvigorate its brand of whiskey, re-imagined to connote the rugged masculinity of the pioneer parable. Mythologies are so efficacious, Barthes (1957) insists, because they appear entirely naturalized. Cultural strategies therefore seek to make a phenomenon appear natural, takenfor-granted, as if second nature. Holt shows that organizations like Jack Daniel's infuse brands with much more than their objective properties; reinvented as 'intertextual constructions' that tap into macro-level cultural codes while chiming with shifts in society-atlarge (Holt, 2006: 359). He explains how the company skilfully built an iconic brand by connecting the micro elements of the firm's unique history, associated with the pre-modern frontier romance, with cultural interactions in the mass market. Notably, the repackaging of historical precedent at Jack Daniel's addressed both an internal, micro-level problem (the need to revive an unprofitable brand) and external currents in the macro-level environment (the fantasy of revivifying the American dream with the gun-slinging masculinity of the frontier myth) (Holt and Cameron, 2010), thereby rendering the strategy particularly efficacious.

The requirement for adept management of an organization's history by skilful organizational actors points to a parallel need for narrative competence on their part. Strategy formulation depends on skilful narratorship to produce belief among stakeholders (Fenton \& Langley, 2011). O’Connor (2002) suggests that the ability to tell a good story is crucial and 
that executives must demonstrate proficiency in narrative sensemaking to succeed in role (Weick, 1995). This is partly because to narrativize is to engage in meaning-making: narratives do not simply mirror reality but construct it and endow it with meaning (Mordhorst, 2014).

Narratives are also bound up with identity. Organizational identity is discursively created from the identity-relevant accounts produced by organizational members (Brown, 2007; Golant, Sillince, Harvey \& Maclean, 2015). Albert and Whetten (1985) describe organizational identity as members' collective understanding of the central, distinctive and enduring features of their host organization, suggestive of fixity and path dependence. Yet narratives unfold and develop over time, shaping identity in the present and future and refashioning perceptions of the past (Halbwachs, 1992; Popp \& Holt, 2013a). This highlights the nature of organizational narratives as dynamic rather than unchanging, implying a degree of fluidity and instability, of 'dynamic repetition', even when the accounts concerned are historical and written in the past (Ericson, 2006: 130).

What is less well understood are the deeper structures and fundamental components of an efficacious rhetorical history such as may have evolved at a large, longstanding organization. The crafting of desired meanings over time demands that actors 'interpret meaning in an intertextual and intertemporal context' (Khaire \& Wadhwani, 2010: 1285). This generates pressures for managers, not least of which is the need to manage contradictions by regulating 'story traffic' when competing narratives collide (O'Connor, 2002: 52).

Here, we add to this debate by suggesting that the active management of an organization's history over an extended period demands particular intertextual competence on the part of executives (O'Connor, 2002). This concerns their expertise to draw on rhetorical accounts of past events and dynamically reshape these as necessary to smooth contradictory 
pressures. Put differently, to sustain belief in a lasting history over time requires not only that the organization retains its inherent essence, but also that it remains sufficiently flexible to react to pressures emanating from the macro-level institutional and competitive environment in which it is located (Selznick, 1949). This places responsibilities on managers, while granting them considerable latitude in interpretive agency. Intertextuality, we suggest, permits the reinterpretation of the organization's narrative in a way that resonates with the consensually derived history recognized by its members; enabling managers to fashion coherent historical accounts consistent with previous versions that remain open to revision. Hence we build on the concept of rhetorical history (Foster et al., 2011; Suddaby et al., $2010 \mathrm{~b} ; 2016)$ to demonstrate how through intertextuality managers with access to historical resources can borrow from these to produce compelling strategies that inspire belief among stakeholders. Skilful intertextual rhetorical strategies enable executives to reconcile the collision of deep-seated structures, indicative of micro-level stability, with their erosion over time due to contradictory pressures stemming from the macro-level environment, facilitating transition (Heracleous \& Barrett, 2001; Li, 2017).

This paper responds to the call for the further integration of history within management and organization studies (Bucheli \& Wadhwani, 2014; Kipping \& Üsdiken, 2014; Rowlinson, Hassard \& Decker, 2014) by adding to the sparse yet burgeoning research on the uses of history in organizations (Foster et al., 2011; Suddaby et al., 2010b). It addresses the need for further empirical work in this domain, which is lacking (Brunninge, 2009). We explore the uses of the past in a large organization endowed with an active archive through the concept of intertextuality, which we introduce as a vital lens through which organizational communication over time, when accessible, may be observed and understood. In doing so, we expand the relatively scant literature on the use of narrative as an active organizational practice in a historical context (Kroeze \& Keulen, 2013; O’Connor, 2002), 
particularly that part of the literature that employs archival analysis as a pillar of its research methodology (Anteby \& Molnár, 2012; Rojas, 2010).

\section{Research Process}

Our research derives from access to selected document classes relating to strategy, internationalization and change management held within $\mathrm{P} \& \mathrm{G}$ 's corporate archives housed at its headquarters in Cincinnati. We decided to limit our study to the six decades beginning in 1950 (when $\mathrm{P} \& \mathrm{G}$ had recovered from wartime disruption) and ending in 2009 (when Alan Lafley ended his first period in office as Chairman-CEO), and to focus our analysis on two main collections of texts: annual reports (shareholder letters and special features) and a collection of 150 speeches made by top executives. These series have the advantage of being relatively evenly distributed across time. Other research materials - including 12 extensive oral history interviews with top executives (four conducted by the $P \& G$ archivist and eight by the authors), company magazines and executive biographies - were used to establish contexts and make sense of key developments and events.

An important preliminary step in the analytical process was to establish the strategic contexts in which texts were produced. We did not seek to document every factor bearing upon particular decisions, but rather to identify the main drivers of strategy within strategic eras, long and distinct periods of history. This involved compiling a financial and activity database detailing P\&G's capital structure, financial performance, sales and earnings by product and territory, and spend on $\mathrm{R} \& \mathrm{D}$, advertising, capital investment, and acquisitions. Strategic statements issued in annual reports were then read against our statistical analysis. The main finding is that between 1950 and $1989 \mathrm{P} \& \mathrm{G}$ pursued a diversified (by product and country) growth strategy before abruptly transitioning to a global (integration) strategy in 1990, which it pursued with ever greater intensity thereafter. This is confirmed in Table 1 by 
the sharp rise in the proportion of total sales and post-tax profits made outside the U.S. after 1990.

\section{[INSERT TABLE 1 HERE]}

In the pre-global era, led successively by Neil McElroy (1948-57), Howard Morgens (1957-71), Edward Harness (1974-81) and John Smale (1981-90), P\&G pursued growth through a combination of product innovation and acquisitions. Its leaders invested in plant (\$703 million per annum, 1975-89), R\&D (2.9\% cost of sales, 1975-89), and advertising (7.8\% of cost of sales, 1975-89). They presided over a decentralized multinational empire in which numerous divisions were run as separate businesses, fundamental to which was the 'conviction that solid and substantial growth in real volume' was key to long-term performance (P\&GCA, 1985). This strategy remained unchallenged before competition intensified and profits slumped in the mid-1980s, when investors began to demand superior returns. Critics - external and internal - questioned the wisdom of prioritizing sales growth over profitability as the key performance metric, suggesting that $\mathrm{P} \& \mathrm{G}$ could do much more to capture potential synergies from its extensive international operations. When, in 1990, Edwin Artzt replaced Smale as leader, he abruptly changed strategic direction, announcing that P\&G's 'major focus will [now] be on global planning ... to achieve maximum competitive advantage' (P\&CCA, 1990). Under Artzt (1990-95) and his successors - John Pepper (199599), Durk Jager (1999-2000) and Alan Lafley (2000-09) - key features of P\&G's historic strategy were intensified, notably investment in plant (\$2,275 million per annum, 19902009), R\&D (4.2\% cost of sales, 1975-89) and advertising (11.4\% of cost of sales, 1975-89). However, these commitments were now allied to global integration, global marketing, cost reduction, and maximizing total shareholder return. Success in these efforts elevated the financial performance of $P \& G$ to a higher plane. 
Having established the existence of two distinct strategic eras, pre- and post-global, we turned to the texts of annual reports and executive speeches to analyse the uses of history in delivering strategy at $P \& G$. Our first reading of the texts was informed by the literatures on intertextuality and rhetorical history as recorded in our literature review. We endeavoured, insofar as possible, to view the texts with fresh eyes and remain open to discovery with respect to form, content and meaning. We identified provisional themes by reading and rereading the texts, but when coding began we found it necessary progressively to refine our ideas (Berg, 2009; Miles and Huberman, 1994). Two researchers independently coded the texts and reconciled differences following discussion. After three rounds, we succeeded in classifying each first-order 'historically redolent text segment' as fitting into one of nine second-order themes (Corley \& Gioia, 2004) specified in Table 2. In this, we provide one illustrative quotation for each theme from both strategic eras.

\section{[INSERT TABLE 2 HERE]}

Further readings of the texts, now collated within nine themes and arranged chronologically, threw into relief three aggregate or 'master themes', each identified with a particular use of the past. The first of these themes concerns the use of the past to aid the socialization of employees. This emphasizes the nature of $\mathrm{P} \& \mathrm{G}$ as a life-world inducing a form of collective lived experience characterized by its own habitus and social structure (Bourdieu, 1990), to which the P\&G population was encouraged to feel it belonged (Halbwachs, 1992; Jenkins, 2000). The need for collective identification increased progressively after 1950, when the company grew rapidly often through acquisition, diversifying into new areas including foods, drinks, oral hygiene and paper, becoming more internationalized, extended and far-flung. Our second category entails the use of the past as invented tradition, involving the inculcation of principles in ways that signalled a 'historic past' whose continuity was partly 'factitious' (Hobsbawm, 1983: 2; Rowlinson \& Hassard, 
1993). Our final category comprises the use of the past as life's educator, imparting lessons to organizational members deriving from history, positive and negative (Kosselleck, 2004). This recognized, as one interviewee expressed it, that 'this kind of history ought to try to record mistakes’ from which the P\&G community could learn and benefit (P\&GCA, 1994b: 49).

Having derived these three aggregate themes, we reflected further on the interrelationships between them and the strategic context in which $P \& G$ operated in the pre-global and post-global eras. Each use of the past, we observed, was implicated in the skilful management of organizational continuity and change. This involved the organization striking a delicate balance between enduring tradition and practical usage as it transitioned between one strategic era and another. Enduring tradition resided in the company's core principles, which lent 'any desired change... the sanction of precedent, social continuity and natural law as expressed in history' (Hobsbawm, 1983: 2). Practical usage, conversely, could not react appropriately to changes in macro-level contexts and remain invariant. Our research indicates that the reassuring continuity of the historical was key to the management of organizational transition, engendering belief amongst internal and external stakeholders that the company was on the right track, its institutional integrity preserved intact (P\&GCA, 1960; 1976; 1996; 2000). Nevertheless, change was clearly vital to keep up with parallel socio-cultural development in the external environment (P\&GCA, 2005).

\section{Intertextual Uses of the Past}

Active use of the past as a strategic resource was a regular practice at $P \& G$ during the entirety of our study period. We know this from various research notes held in the archive, and from the testimony of archivists and executives. As Interviewee B (2011) confirmed:

'If you look back there are all sorts of quotes. One of the earliest is that Procter said we deal in fair measures, if you cannot find a way to do business using fair measures and honest trading you should go and find something else to do. There are lots of others.' 
We can infer the same from the repeated use of ideas, phrases and stories in documents like annual reports and speeches. The illustrative pairs of text segments in Table 2 suggest a high degree of thematic continuity within the $P \& G$ intertext resulting from executive familiarity with the (rhetorical) history of the company, likely acquired both textually and conversationally. Our interest, however, lies not just in continuity, but also in change. How have $P \& G$ executives drawn upon, modified and added to the $P \& G$ intertext in pursuit of discontinuous change? In particular, how was the pre-global past used to help transition to the post-global future?

\section{Socializing employees}

There is no doubt that historically $P \& G$ leaders nurtured a deeply held belief that the company's competitiveness depended substantially on its people (P\&GCA, 1976). This is evident in numerous signs of adherence to a value compass or set of ethical principles according to which the company operated (Ericson, 2006). To institutionalize is 'to infuse with value' (Selznick, 1957: 17). P\&G's espoused values were inculcated largely through repeated reference to the past (Suddaby et al., 2010b), employees being socialized into what Pepper described as a 'hand me down culture' (P\&GCA, 1995: 1). Organizational socialization entails the ways in which employees' experiences, especially those of new recruits, 'are structured for them by others within the organization' (Van Maanen, 1978: 19). Acculturation is reputed to enhance organizational performance (Denison \& Mishra, 1995). In socializing employees in the pre-global world, $P \& G$ executives highlighted the implicit 'social contract' that had underpinned the company's growth: in return for talent, initiative, commitment, flexibility and loyalty, employees could expect good salaries, a share in profits, guaranteed employment, promotion opportunities and fringe benefits.

The $P \& G$ documentary record is typified by 'intertextual chains' designed to achieve social structuring by imparting regular lessons on social practices while signposting for the 
future. These lessons focus on corporate attributes legated from the past and imputed to have enduring value; each encapsulated in a memorable phrase such as people are the company's greatest asset, we promote from within, we believe in doing the right thing, we prize individual initiative, and we gain competitive advantage through the character of the company. Take, for example, the oft-repeated mantra of doing the right thing, attributed to Richard Deupree, the first CEO from outside the founding families (1930-48). In 1973, Howard Morgens delivered a year-end management dinner speech where he stressed 'we try to do the right thing at all times' (P\&GCA, 1973: 6). Three years later, CEO Ed Harness borrowed from this speech by Morgens to affirm the importance of 'doing the right thing at all times - not what is expedient but what is right' (P\&GCA, 1976: 7). Twenty years on, Pepper highlighted the importance of 'doing the right thing' as key to P\&G's enduring success (P\&GCA, 1995: 1); its importance seemingly amplified as the company struggled with a worsening competitive environment.

Allied to this was the importance of character which McElroy identified as the single most prized quality in $\mathrm{P} \& \mathrm{G}$ employees: 'The Company rates character in its people higher than any other single quality. We are raised in that tradition and we are trained to perpetuate it' (P\&GCA, c.1957). Three years later, in 1960, a senior vice-president, Walter Lingle, in a speech to top management, elevated character from an individual quality to a shared characteristic. Lingle identified 'thoroughness', 'self-discipline', 'individual initiative', 'team work', 'good communication', 'good citizenship', 'ethical correctness', 'development of talent', 'leadership' and 'competitiveness' as the main elements of P\&G's character, together creating 'distinctiveness' and inducing 'a feeling of great pride' (P\&GCA, 1960). A succession of P\&G CEOs echoed Lingle. For Morgens 'the strength and character of the Company was a reflection of the high quality of its people' (P\&GCA, 1961); for Harness character was an 'underlying asset which holds us together in times of change or stress' 
(P\&GCA, 1981); for Smale promotion from within was essential for employees to 'develop a deep sense of the Company's character' (P\&GCA, 1982); for Artzt it was a source of 'great pride ... [that we] place character above all other qualities' (P\&GCA, 1994).

The theme of character intertwined with that of people being the company's greatest asset in both the pre-global and post-global strategic eras. Necessarily, however, as P\&G embraced the logic of globalization, its historical account, as a management tool, needed to adapt to retain its potency. Large-scale redundancies, implemented in waves during the 1990s and 2000s, violated the implicit social contract that existed between company and employees. P\&G was no longer prepared to guarantee lifetime employment. In 1994, when Artzt announced the loss of 13,000 jobs, he recognized the 'disruption these decisions can create', but he had promised shareholders to cut costs and 'accelerate our pace of future earnings growth' (P\&GCA, 1994: 12). In justifying this change, he updated the $P \& G$ intertext for the global era. Under the heading 'unchanging values in changing times' he expressed his pride in working 'for a Company that places integrity above all else, a Company that believes in always trying to do the right thing.' Downsizing was painful, but it was 'unavoidable', and while 'the Company's people come and go, the values that bind us together are permanent' (P\&GCA, 1994: 15). In other words, corporate values trumped long-established practices when taking big decisions, even if abandoning such practices contravened these values in the process.

This was a profound shift, flexing the $\mathrm{P} \& \mathrm{G}$ intertext to the requirements of globalization. When, in 2001, Pepper announced another round of mass redundancies, the legitimating formula devised by Artzt was replayed. Facing one of the 'toughest decisions of his career', Pepper went back 'to something a former CEO of the Company, R.R. Deupree, said 50 years ago: "Try to do the right thing".' It saddened him to disrupt so many lives, but it was vital to reduce costs. He concluded that while 'moments like this test our commitment to 
our Principles and Values, in substance and perception ... we will hold onto them as something special to our Company [as] we have done so through every challenging period of our history’ (P\&GCA, 2001).

In the pre-to-post global transition at $\mathrm{P} \& \mathrm{G}$, words borrowed from the past were thus used to justify incremental change that culminated over time in change that was far-reaching. The dynamic repetition of the sayings of past executives was intended to make transition more acceptable to stakeholders by casting it in the reassuring hue of continuity. Discourse influences action by revealing contradictory actions as inherently problematic (Phillips et al., 2004). At $P \& G$, however, actions that contradicted the intertext were made to appear more palatable by presenting them as continuity, promoting identification (Burke, 1969). A further example of this occurred under Lafley, when globalization became the dominant cultural discourse, prompting a major shift in focus from a regional to a globally led business. This precipitated the divestment of numerous products which, though lucrative, did not yield billion-dollar sales and hence were 'non-strategic' (Interviewee D, 2015). The upshot was the divestment of P\&G's entire food business, much tailored to regional tastes, including highly profitable brands like Pringles and Folgers coffee. This disjuncture was nevertheless portrayed as conforming to the longstanding pursuit by $P \& G$ of blockbuster brands.

\section{Inventing tradition}

The weaving of a historical account enables a new angle to be superimposed on a particular event to recast it in a positive light in the manner of 'invented tradition' discerned by Hobsbawm (1983). P\&G's invented tradition of adherence to an unchanging set of core values provides a compelling example. This went hand-in-hand with the celebration of $P \& G$ as a company propelled by research, innovation and market-leading brands. It is in the tradition of innovation (in technology, products and marketing) that $\mathrm{P} \& \mathrm{G}$ claims distinction, its ultimate source of competitive advantage. As Interviewee B (2011) put it, 'Innovation, 
innovation, innovation. We say it's in the company's life blood'. According to corporate mythology, the tradition began with P\&G's launch in 1879 of Ivory soap 'after four years of painstaking research' (P\&GCA, 1979). This white vegetable soap, claimed to be $99.5 \%$ pure, had the singular quality of floating in water. Ivory was launched and sustained by mass marketing throughout the U.S. and became the engine of future growth, the totemic $P \& G$ brand (Dyer et al., 2004: 23-41). The 1987 annual report quotes from a letter by James Gamble 100 years previously, where he observes: 'There is as much progress in soapmaking as in anything else and we keep ourselves in the forefront always' (P\&GCA, 1987: 13).

Innovation and related themes form a dense network of intertextual chains within the $P \& G$ historical account. This is confirmed by repeated reference to innovation in annual reports and executive speeches. Three main claims are made: that $P \& G$ has been the originator of numerous breakthrough products; that continuous product improvement keeps P\&G brands competitive over long periods; and that P\&G's innovative capacity stems from its understanding of customer needs. These claims were often interwoven, as when Jager observed that 'innovation... is a discontinuous way of satisfying customer needs' (P\&GCA, 1991a: 4). Reference to history is one of the most persuasive ways of sustaining these claims, and the 1987 annual report, marking the company's $150^{\text {th }}$ anniversary, is exemplary in this regard. Here, we are told that 'a superior understanding of consumers and their needs is the foundation on which we build our business.' $P \& G$ had always 'listened to its customers' but since 1923 had created a sophisticated market research capability to identify 'emerging consumer needs' that guided research to improve existing products or develop breakthrough products. Crest is cited as a standout example of the latter category, providing in 1955 a 'scientific breakthrough' in dental care through which 'P\&G became the first to successfully put fluoride in a toothpaste' enabling it to dominate the toothpaste market (P\&GCA, 1987). Re-telling the story at the dawn of the global era, Artzt concluded that Crest 'changed forever 
the way consumers and dental professionals dealt with oral hygiene' just as P\&G's introduction of the synthetic detergent Tide in 1946 had 'provided better cleaning power than ever imagined' (P\&GCA, 1991a: 4).

No product is of greater mythological significance to $P \& G$ than Tide. Widely regarded as the world's first synthetic detergent, its story is recounted at length in P\&G's commissioned history, Rising Tide (Dyer et al., 2004: 67-84). This tells how during World War II, an unorthodox researcher, David Byerly, worked without official approval on the development of 'Product X', making a 'counterintuitive breakthrough' on inverting the builder-surfactant proportions used for his experiments (Dyer et al., 2004: 73). The new formula was unveiled to $P \& G$ managers in the last year of the war. This dominant story of the invention of Tide provides a satisfactory explanation as to why its development was not fully embedded within the company's R\&D strategy. Having originated from a structure that promoted individual initiative, it emerged 'on the periphery of the company', outside formal channels (Dyer et al., 2004: 75).

Closer scrutiny of the story of Tide suggests a narrative strategy that actively puts in parenthesis a counter narrative. According to this alternative account, the first synthetic detergent was invented by the German firm, Henkel. As Vice president Tom Bower candidly acknowledged, 'We picked it all up, of course, in the early thirties from Germans. I'm married to the daughter of the man that did that' (P\&GCA, 1994d: 16). Owen Butler corroborates this:

'This Company, throughout its history, has had the capacity to take a technological advance, no matter who invented it, and to look at it as a way to create a better product rather than a cheaper product... What we did was figure out a way to really take this new type of inferior detergent and make it a superior product'. (P\&CGA, 1994c: 24, our emphasis)

Tide is accorded such significance in P\&G mythology because the company 'finally had a product that really would compete internationally' (P\&GCA, 1993: 19). However, the real 
success story, we suggest, concerns how $P \& G$ stole a march on its rivals in synthetic detergents. This narrative is bracketed and left untold, supplanted by the sanctioned narrative of $\mathrm{P} \& \mathrm{G}$ as the inventor of an original, ground-breaking product. The latter offers a more attractive account to one that openly acknowledges Henkel's role in the process. Anteby and Molnár (2012) tell an analogous story about the French aircraft manufacturer Snecma, noting that the vital role played by German engineers in its development is simply ignored. The point to stress here is not that the story of Tide as told by $P \& G$ is deliberately disingenuous, but rather that it occupies a special place in the panoply of P\&G's cultural mythology as a paragon breakthrough brand for other innovations to emulate, while exemplifying how $P \& G$ likes to beat the competition. As Gagliardi (1986: 124) states:

'Factual evidence is lost as generation succeeds generation in the organization... Thus, in any organization... there is a nucleus of "revealed" truths which have been passed on through the years and which have been incorporated into the mythical constructs that we commonly define as "tradition".

When storylines collide, intertextual competence is required to reconcile competing versions (O'Connor, 2002). The main function of the preferred account on this occasion is to suppress historical evidence for the purposes of 'sensehiding' to enhance legitimacy (Vaara \& Monin, 2010). This simplifies a narrative that might otherwise imply P\&G had profited from a rival's invention, while emphasizing individual initiative. The tale of maverick 'hero' Byerly side-lines Henkel's part in the story, rewriting the organizational memory of the event. A key insight here is that studying archival texts intertextually, tracing the evolution of a particular thematic, may alert us to anomalies such as this. The cultural branding of Tide in the manner explored by Holt (2004) suggests P\&G is acutely aware of the role history may play as a potent source of competitive advantage (Suddaby et al., 2010b).

\section{Learning from history}

$P \& G$ executives have consistently recognized the quintessential importance of striking historical examples in providing a yardstick against which strategic options may be 
measured. Historical exemplars endow 'strategic ideas for the future with an appropriate historical heritage', serving as a basis for action and providing a powerful lens through which decision-making may be appraised (Brunninge, 2009: 21). One such example concerns the constant search for disruptive innovations, for the breakthrough product epitomized by Ivory or Tide, accorded quasi-mythical status at P\&G. Repeated references to Tide in the P\&G intertext are designed to promote 'risks to identify game-changing, life-enhancing innovations' (Lafley \& Charan, 2008: 80, 222). Artzt clarifies its historic symbolism as follows:

'Every competitor is looking for ways to gain the lead. History has shown that this takes a real breakthrough - a discontinuity - something that consumers recognize as a distinctly better product. Tide accomplished this in the 1940s ... Consumers flocked to it, and before long, the entire industry converted from soap to detergents.' (P\&GCA, 1991b: 2)

Coupled with its micro-level symbolism inside $\mathrm{P} \& \mathrm{G}$, this extract elicits the status of Tide as a formidable macro-level game-changer that radically altered the entire industry.

Beyond the symbolic, history affords present leaders the opportunity to learn from their predecessors and engage in historical sensemaking as part of the strategy process; historical reasoning about time past representing a key component of the ongoing organizational sensemaking process (Maclean, Harvey, Sillince \& Golant, 2014; Wadhwani \& Jones, 2014). This entails using history to help the organization through difficult times by evoking the words and lessons of past leaders which offer a way forward. Harness exemplifies this point:

'Many years ago... I heard Mr Deupree [say] the Company always tried to be about right... Human nature and capabilities being what they are, we cannot expect to be continually $100 \%$ right. However, we always have been willing and always shall be willing to make the extra effort to look at the long-term consequences of every decision. Then, based on our total assessment of the future, we try to make the decision that will be about right'. (P\&GCA, 1981: 26)

The lesson to be drawn here is that whatever difficult decisions executives may have to take in the future, the $P \& G$ community can be confident that they will be 'about right'. The 
lessons of history are inevitably also derived from past mistakes. In a company preoccupied with innovation, which places great store by the 'freedom of individual initiative' (P\&GCA, 1976: 9), Lafley emphasizes the importance of trial-and-error and the latitude to make mistakes:

'When I joined P\&G in the 1970s... I spent two years working on a secret new product innovation called H-85. It never made it to marketplace. I was concerned. Would I get another assignment after toiling on a failure? I did, and I have had a long career'. (Lafley \& Charan, 2008: 222)

Butler confirms that tolerance of mistakes as a source of learning was deeply ingrained at $\mathrm{P} \& \mathrm{G}$, relating how Morgens had once given his younger self permission to make an 'affordable mistake' as part of his training, telling him: 'my function is to prevent young managers like you from making unaffordable mistakes. This is an affordable mistake, go ahead and make it' (P\&GCA, 1994b: 59). P\&G's entry into Japan in 1972, however, was a more serious case in point. International assignments were used to broaden managers' experience of global-local challenges. However, for many years $P \& G$ tended to expand internationally by marketing U.S. products without paying sufficient heed to varying cultural contexts. After several difficult years, it was clear the Japanese campaign had failed, and P\&G had to decide whether to write off the experience or commit to re-entry. In 1985 , the situation was rectified through the adoption of a five-point strategy built around understanding Japanese consumer specificities and penetrating the country's distribution system (P\&GCA, 1988b). P\&G later used the lessons learned in Japan to effect a more successful entry into China (Dyer et al., 2004).

\section{Continuity and change}

Each of the preceding themes informs the master theme of continuity and change across two strategic eras at $\mathrm{P} \& \mathrm{G}$; the company transitioning from being a loosely structured multinational to an integrated global enterprise. With this transformation came the challenge of preserving institutional integrity despite major disruptions in policy and operations, of 
justifying strategic change even when this was profound (Selznick, 1957). This was made explicit by Lafley in an address to $P \& G$ alumni in 2005. After recalling various teachings of past CEOs, dubbed 'stewards of P\&G', including Smale, Artzt, Pepper and Jager, Lafley summarized as follows: 'You can go back through P\&G's history and find similar observations, similar sentiments, across the generations... Today, more than 100,000 women and men of character feel this same responsibility' (P\&GCA, 2005: 9). Notwithstanding the loss of control executives may feel when faced with perturbations in the external environment, it is their job to manage inconsistencies in the organization's narrative over time (O’Connor, 2002).

Hence, the $\mathrm{P} \& \mathrm{G}$ intertext comprises a documentary record woven by different managers to manage change within continuity. Each can draw on the speeches of past leaders through their availability in the archives, which provide the 'continuing counsel of [their] predecessors' (P\&GCA, 1981: 32). This underlines the nature of history as process, to which the interlinking of texts lends order and direction, admitting amendments as changes arise (Popp \& Holt, 2013b; Wadhwani \& Jones, 2014). This process gained tempo at P\&G after the relative stability of the pre-global strategic era. Most especially, breaking the social contract between company and employees tested the intertextual competence of the $P \& G$ leadership as they sought to elevate the shareholder interest above that of other stakeholders. $\mathrm{P} \& \mathrm{G}$ managers emerge not just as producers of texts but more importantly as interpretive agents, reconciling contradictory elements of an evolving narrative into a coherent whole. Total consistency is not exacted; room must be afforded to accommodate the new while signalling continuity with history. This implies 'compliant interpreters... who fit in with positions set up for them in texts' (Fairclough, 1992: 291), underlining the need for new leaders to be assimilated into the $\mathrm{P} \& \mathrm{G}$ story thus far. Thus, when change is instigated, as when global integration leads to the dissolution of cherished structures and practices, this 
discontinuity is presented not as a strategy which gainsays narrative integrity but as one which conforms to the longstanding storyline of having the character to do the right thing, through which the new strategy is legitimated (Chreim, 2005).

This illustrates the possibilities organizational history may afford for reconstruction (Brunninge, 2009). Viewed in this light, history emerges as a vital means of enabling P\&G to 'learn to change and yet somehow stay the same'; facilitating what Gioia et al. (2000: 64) label 'adaptive instability'. This permits a degree of flexibility amid shifting external landscapes whilst setting the parameters of the organizational narrative with which the company's evolving story must harmonize. In this way, the developing storyline is presented as 'stable to perceivers, even as it changes' (Gioia et al., 2000: 72). Gagliardi (1986) argues that organizations change in order to stay what they have consistently been. This emphasizes a form of 'dynamic consistency' (Gioia et al., 2000: 79) that elucidates the importance of the intertext as an enabler of strategic change.

\section{Discussion and Conclusion}

At the start of this paper, we posed two guiding research questions. We asked, first, what were the primary uses to which the past has been deployed at $\mathrm{P} \& \mathrm{G}$ over its history? Second, we enquired what role intertextuality might have played in the social construction and evolution of the $P \& G$ narrative during its transition from multinational to global enterprise? In answer, we suggest that the uses of the past at $P \& G$ during the time of our study were inextricably bound up with a socially constructed organizational intertext that fulfilled several functions, summarized in Table 2. Its first purpose concerned the socialization of employees, fostering identification, especially during acquisition and diversification into new geographies. The socialization of employees of acquired firms was especially critical, as confirmed by Interviewee C (2011), a former employee of India-based Richardson Vicks: 
There were always stories people told about "well, this is what we did in '64; this is what we did in ' 82 ", and they used these when they were supporting an argument, like arguing on case law in the court you referred back to these stories and then people were reminded how $P \& G$ had done it then.

Its second function had to do with the exploitation of the past as invented tradition to nurture a robust company mythology (Hobsbawm, 1983; Holt, 2006). This entailed not only mythologizing about historical breakthrough brands like Tide, but more importantly mythologizing about $P \& G$ itself as being 'more than a company' but rather 'an institution and community' (P\&GCA, 2003: 1). Its third usage involved conveying lessons for the present and future deriving from its history (Kosselleck, 2004). Each of these uses informed the management of strategic change while preserving cultural continuity (March, 1996).

Central to this, especially in the harsher environment of the post-global era, was the maintenance of what were described as 'timeless values':

We are dedicated to upholding a few timeless values - integrity, respect for the individual, doing the right thing. $P \& G$ 's timeless values are rooted in the early belief of the founders and subsequent family members in the business. (P\&GCA, 1995: 1)

The emphasis on timelessness suggests mythmaking of a quasi-spiritual character, which goes above and beyond the changes that the firm and market are undergoing in regular 'historical time'. It was indeed as a 'spiritual inheritance' from the founders that such values were collectively presented (P\&GCA, 1976: 4). Myth is a social stereotype passed off as natural (Barthes, 1957). The construction of timeless values through intertextuality accentuates the mythical quality of these values, which, while seemingly banal to outside observers, nevertheless constitute beliefs to those inside the organizational culture. This belief in timeless values was endowed with spiritual overtones, evoking the myth of 'a community truly built to last - generation after generation - forever' (Pepper, 2005: 281).

In weaving the $P \& G$ intertext, $P \& G$ managers engaged in linguistic practices that anchored the organization's history to its ongoing and future prosperity (Foster et al., 2011). They developed interpretations not only within but across texts, elaborating themes which 
transferred received wisdom from previous decades and leaders in a dynamic repetition blended with incremental change (Ericson, 2006). The power of myth is operationalized through its recurrence (Barthes, 1957). Repetition is a vital means whereby cultural strategies succeed and become dominant (Harvey, Press \& Maclean, 2011; Holt, 2006). It is a crucial aspect of rhetorical history, fostering identification and the sense of belonging to an 'imagined community', enabling change while seemingly staying the same (Anderson, 1983; Suddaby et al., 2016). Archival searches highlight the difference in repetition, uncovered in an intertextual trail when the trajectory of a particular thematic is traced over time (Deleuze, 2004). The difference in repetition may reflect new discourses circulating in the macro-level environment, as when $\mathrm{P} \& \mathrm{G}$ downsized during the 1990s financial crisis. The large-scale redundancies that ensued flew in the face of people being the company's greatest asset; but they resonated with a wider lexicon of corporate legitimation as numerous organizations employed similar global restructuring strategies, necessitating an intertextual rhetorical strategy to reconcile the contradiction and bridge the micro-macro gap (Li, 2017). Seeing the difference in repetition may highlight the diametric opposite of an original intention, as when issuing redundancies was translated as another way of doing the right thing: 'there is no way anyone could do what's right without taking on such decisions' (Pepper, 2005: 154). This enabled $P \& G$ to change while seemingly staying true to its core values.

The latitude of P\&G managers to interpret the organization's history was arguably limited by the requirement to tell and live by the socially constructed storylines that together comprised the company's mythology. In this they were restricted by historical legacy and the expectations of the $\mathrm{P} \& \mathrm{G}$ community, past and present. Yet innovation is not stand-alone but responds to wider historical and societal change within which it is embedded (Holt \& Cameron, 2010). Managers face pressures to attune their strategies to changing cultural codes 
at the macro-level, resonating with change more broadly in societal and competitive environments. As Porter (1986: 41) clarifies:

'We are constrained insofar as we must borrow the traces, codes, and signs which we inherit and which our discourse community imposes. We are free insofar as we do what we can to encounter and learn new codes, to intertwine codes in new ways'.

While the historical narrative may be constraining, the principles it lays down proving ever trickier to adhere to, our analysis suggests that digressing too dramatically from its parameters may prove costly to the organization (Phillips et al., 2004). This sensitive balance was arguably upset when the pursuit of blockbuster brands was reinterpreted to mean the divestment of profitable regional products deemed 'non-strategic' (Interviewee D, 2015). In this case, the narrative provided comforting camouflage, allowing a new direction which contradicted institutional integrity to be presented as in keeping with the company's longstanding pursuit of champion products. On the other hand, sticking too rigidly to past principles that may have run their course, exemplified by the emphasis on people and values in the teeth of lay-offs caused by changing macro-level conditions, may be equally ill advised. Contravening expectations tests the belief of key stakeholders in the company's ongoing strategy. In this sense, the guidelines offered by the P\&G intertext are helpful, signposting a pathway to the future.

We make two main arguments with respect to intertextuality and the uses of history in the pre-global and post-global eras at P\&G. Our first is that in the transition from multinational to global enterprise, recognition of the value of history to the delivery of strategy increased rather than diminished. $P \& G$ drew more extensively on its archival resources to socialize employees, invoke tradition, and learn from the past. This intensification in uses of the past was largely a function of its expanding scale and scope and the manner of its growth. Globalization was predicated on integration, simplification and a much sharper focus on global brands across an ever increasing number of host countries. 
Local variations in practices and preferences were displaced by centrally imposed standards justified in no small measure by P\&G's history. History demonstrated and legitimized the imposition of the $\mathrm{P} \& \mathrm{G}$ way of doing business. This was especially important when integrating large acquisitions like Richardson Vicks, whose employees were expected rapidly to embrace $P \& G$ standards, procedures and expectations.

Our second argument is that the links added to intertextual chains in the post-global era were forged differently from those of the pre-global era. What is striking about the preglobal era is the high degree of consistency in form and content of texts as the same messages were replayed across generations, integral to social reproduction, reinforcing the strategic and organizational status quo. These texts were often very specific, locating the origin, person responsible and precise logic of the ideas communicated. After the disjuncture of globalization, the historically more authentic messaging of the pre-global era was replaced by more rhetorically intense variations on long-standing themes. In the new era, old policies, practices and values, which varied across sites, divisions and territories, were jettisoned in favour of uniform alternatives. In this new organizational environment, rhetorically supercharged history served to reassure and strengthen the commitment of employees, consumers and investors to $\mathrm{P} \& \mathrm{G}$ as a global institution.

The most compelling difference between the pre-global and post-global strategic eras relates to organizational purpose. In the pre-global era, the leaders of $P \& G$ assumed a stakeholder worldview. The company was there to serve its customers, employees, shareholders and the communities in which it operated. The job of top management was to grow the business for the benefit of all stakeholders; executives took a long-term view and believed that if turnover increased profits would follow. Going global was underpinned by a profound ideological shift such that $\mathrm{P} \& \mathrm{G}$ leaders now prioritized total shareholder returns. In the new world, capital was no longer patient, but demanded that earnings be maximized in 
the here and now. The organizational purpose was transformed as other stakeholders were subordinated to shareholders. This was disguised substantially by the on-going invocation of historical themes and references emphasizing continuity with the past.

A limitation of this research is that it is based on a single case study. Whether the particular mix of uses of history found at $P \& G$ is common or exceptional remains to be established. More research is needed. This said, we believe that P\&G's longstanding maintenance of a working archive suggests it may be an 'extreme case', worthy of study in its own right (Eisenhardt, 1989), especially given access to the rich documentary sources and complementary oral histories available to the research team. It must be admitted, though, that most documentation in organizational archives pertains to managers (Delahaye, Booth, Clark, Procter \& Rowlinson, 2009). That the P\&G intertext features the voices of management prominently suggests our understanding might be shaped by the power relations that characterized an organization reputed to be 'top-down'; where, over time, the incumbent CEO was described as increasingly 'imperial' (Interviewee A, 2008).

Our research contributes to the new organizational history (Bucheli \& Wadhwani, 2014; Suddaby et al., 2010b), which seeks to integrate history with organization theory (Kipping \& Üsdiken, 2014; Maclean et al., 2016; 2017; Rowlinson et al., 2014), especially through archival analysis (Anteby \& Molnár, 2012; Rojas, 2010). We suggest that organizational archives when used purposefully promote intertextuality by fostering interaction between past and present managers. We highlight the role of intertextuality as a powerful manipulative tool used, first and foremost, by managers as interpretive agents directing strategic change while mindful of enduring values, and secondly by researchers examining the twists and turns of an organization's rhetorical history.

We make a contribution to elaborating the construct of rhetorical history, in which empirical studies are lacking, by demonstrating how intertextuality provides a useful 
illustrative instance of the ways in which rhetorical history actually works in practice. We show how the potentially valuable, rare, inimitable and malleable resource of an organizational history (Suddaby et al., 2010b; 2016) can be reworked through intertextual manipulation to produce continued belief among stakeholders. Little is known about the deeper structures and key components of a company's rhetorical history. We propose in response three categories that form its fundamental raisons d'être: socializing employees, inventing tradition, and learning from history. Textual borrowings from the past sharpen the impact of a company's rhetorical history by lending legitimacy, substance and direction. Exploring an organizational history intertextually uncovers the textual manipulations behind the organizational rhetoric, revealing how an impression of coherence can be maintained in the face of evident discontinuity, rallying stakeholders to a new strategic vision through the repackaging of historical precedent.

In building on the concept of rhetorical history, we make a fresh contribution to the growing literature on historical organization studies (Maclean et al., 2016; 2017), to which we introduce new understanding drawn from literary theory. At the same time we advance understanding of intertextuality by demonstrating its practical usage as a management tool to facilitate strategic change. This focuses attention on the manipulative power of the archive and the high degree of interpretive agency of those who direct strategic change, identifying them as 'deliberate actors [who] act as mythologists... or as myth producers who manipulate signs' (Li, 2017: 544). Skilful intertextual agency enables the reworking of longstanding thematics to dissipate inherent tensions when internal culture and external pressures collide; encouraging identification with the new strategy by emphasizing continuity, even when it contravenes past practice. In this way, interpretive agency facilitates openness to 'major and often unexpected change', while the organization nominally keeps faith with espoused values (Pepper, 2005: 271). 
In conclusion, our first core insight is to discern that in the transition from multinational to global enterprise, cognizance of the value of history to delivering strategy intensified. Our second key insight is to recognize that the historically more authentic messaging that typified the pre-global era ceded in the post-global era to more rhetorically intense variations on time-honoured themes. Together, these insights suggest that when global competitive pressures dictated change, executives had to work harder to exhibit continuity with the past. Our main contribution to theory is to demonstrate how sensitivity to intertextuality reveals organizational history as historically constructed through language, subject to the agency of skilful interpretive actors who perform intertextual adaptation in pursuit of strategic change. This supersedes any notion of an objective historical reality in favour of more malleable social realities open to refashioning by the strategic manipulations of interpretive agents within organizations (Heller, 2016). Intertextual rhetorical strategies become harder for organizational members to counter and resist when they resonate with cultural strategies circulating more widely; as in the post-global era, when global restructuring strategies and a focus on shareholder value became prominent. It is the capacity to connect specific elements of the micro-practices of the organization to broader cultural strategies emerging in the institutional environment that make intertextual rhetorical strategies so effective (Holt, 2006).

Foregrounding interpretive agency in this way shines a light on the nature of organizational history as a process that allows for intertextual re-ordering (Wadhwani \& Jones, 2014; Popp \& Holt, 2013b). This highlights the importance of time in corporate strategizing and the nature of management as shared interpretive agency across time as well as space (Raff, 2013). While extant research has shown that agency may be distributed interpersonally and contemporaneously (Garud \& Karnoe, 2002), we demonstrate that it may also be distributed across time, intertextually and intertemporally, through which the voices 
of past strategists combine with incumbents to reshape strategy as purposes and contexts evolve (Khaire \& Wadhwani, 2010).

\section{References}

Albert, S. and Whetten, D. (1985). Organizational identity. In L.L. Cummings \& B.M. Staw (Eds.), Research in organizational behaviour, 7, 263-295. Greenwich, CT: JAI Press.

Allen, G. (2011). Intertextuality. (2 ${ }^{\text {nd }}$ ed.). London: Routledge.

Anderson, B. (1983). Imagined communities: Reflections on the origin and spread of nationalism. London: Verso.

Anteby, M. and Molnár, V. (2012). Collective memory meets organizational identity: Remembering to forget in a firm's rhetorical history. Academy of Management Journal, 55, 515-540.

Barry, D. and Elmes, M. (1997). Strategy retold: Toward a narrative view of strategic discourse. Academy of Management Review, 22, 429-452.

Barthes, R. (1957). Mythologies. Paris: Editions du Seuil.

Barthes, R. (1977). Image - music - text. Fontana: London.

Berg, B.L. (2009). Qualitative research methods for the social sciences. $7^{\text {th }}$ edn. Boston, MA: Allyn \& Bacon.

Boje, D.M. (2008). Storytelling organizations. London: Sage.

Bourdieu, P. (1990). The logic of practice. Cambridge: Polity.

Braudel, F. (1980). On history. Chicago: University of Chicago Press.

Brown, A.D. (2007). Organizational identity. In S.R. Clegg \& C. Cooper (Eds.), Handbook of Macro-Organizational Behaviour. London: Sage.

Brunninge, O. (2009). Using history in organizations: How managers make purposeful reference to history in strategy processes. Journal of Organizational Change Management, 22, 8-26.

Bucheli, M. and Wadhwani, R.D. (Eds.) (2014). Organizations in time: History, theory, methods. Oxford: OUP.

Burke, K. (1969). A rhetoric of motives. Chicago: University of Chicago Press.

Casey, A.J. and Olivera, F. (2011). Reflections on organizational memory and forgetting. Journal of Management Inquiry, 20, 305-310. 
Chreim, S. (2005). The continuity-change duality in narrative texts of organizational identity. Journal of Management Studies, 42, 567-93.

Corley, K.G. and Gioia, D.A. (2004). Identity ambiguity and change in the wake of a corporate spin-off. Administrative Science Quarterly, 49, 173-208.

De Certeau, M. (1988). The writing of history. New York: Columbia University Press.

Delahaye, A., Booth, C., Clark, P., Procter, S. and Rowlinson, M. (2009). The genre of corporate history. Journal of Organizational Change Management, 22, 27-48.

Deleuze, G. (2004). Difference and repetition. London: Continuum.

Denison, D.R. and Mishra, A.K. (1995). Toward a theory of organizational culture and effectiveness. Organization Science, 6, 204-223.

Durepos, G. (2015). ANTi-History: Toward amodern histories. In P.G. McLaren, A.J. Mills \& T.G. Weatherbee (Eds.), The Routledge companion to management \& organizational history: 153-180. London: Routledge.

Durepos, G. and Mills, A.J. (2012). Actor-network theory, ANTi-history and critical organizational historiography. Organization, 19, 703-721.

Dyer, D., Dalzell, F. and Olegario, R. (2004). Rising tide: Lessons from 165 years of brand building at Procter \& Gamble. Boston, MA: Harvard Business School Press.

Eisenhardt, K. (1989). Building theories from case study research. Academy of Management Review, 14, 532-550.

Ericson, M. (2006). Exploring the future exploiting the past. Journal of Organizational Change Management, 12, 121-136.

Fairclough, N. (1992). Intertextuality in critical discourse analysis. Linguistics and Education, 4, 269-293.

Feldman, R.M. and Feldman, S.P. (2006). What links the chain: An essay on organizational remembering as practice. Organization, 13, 861-887.

Fenton, C. and Langley, A. (2011). Strategy as practice and the narrative turn. Organization Studies, 32, 1171-1196.

Foster, W.M., Coraiola, D., Suddaby, R., Kroezen, J. and Chandler, D. (2016). The strategic use of historical narratives: A theoretical framework. Business History, forthcoming.

Foster, W.M., Suddaby, R., Minkus, A. and Wiebe, E. (2011). History as social memory assets: The example of Tim Hortons. Management \& Organizational History, 6, 101120.

Gagliardi, P. (1986). The creation and change of organizational cultures: A conceptual framework. Organization Studies, 7, 117-134. 
Garud, R. and Karnoe, P. (2002). Bricolage versus breakthrough: Distributed and embedded agency in technological entrepreneurship. Research Policy, 32, 277-300.

Garud, R. and Nayyar, P.R. (1994). Transformative capacity: Continual structuring by intertemporal technology transfer. Strategic Management Journal, 15, 365-385.

Gioia, D.A., Schultz, M. and Corley, K.G. (2000). Organizational identity, image and adaptive instability. Academy of Management Review, 25, 63-81.

Goffman, E. (1969). The presentation of self in everyday life. London: Penguin.

Golant, B.D., Sillince, J.A.A., Harvey, C. and Maclean, M. (2015). Rhetoric of stability and change: The organizational identity work of institutional leadership. Human Relations, 68, 607-631.

Halbwachs, M. (1992). On collective memory. Chicago: University of Chicago Press.

Harvey, C., Press, J. and Maclean, M. (2011). William Morris, cultural leadership and the dynamics of taste. Business History Review, 85, 245-271.

Heller, M. (2016). Foucault, discourse, and the birth of British public relations. Enterprise \& Society, 17, 651-677.

Heracleous, L. and Barrett, M. (2001). Organizational change as discourse: Communicative actions and deep structures in the context of information technology implementation. Academy of Management Journal, 44, 755-778.

Hobsbawm, E. (1983). Introduction: Inventing traditions. In E. Hobsbawm and T. Ranger (Eds.) The invention of tradition, 1-14. Cambridge: CUP.

Holt, D.B. (2004). How brands become icons: The principles of cultural branding. Cambridge, MA: Harvard Business Press.

Holt, D.B. (2006). Jack Daniel's America: Iconic brands as ideological parasites and proselytizers. Journal of Consumer Culture, 6, 355-377.

Holt, D.B. and Cameron, D. (2010). Cultural strategy: Using innovative ideologies to build breakthrough brands. Oxford: OUP.

Interviewee A. (2008). Life history interview, 18 July 2008, London, UK.

Interviewee B. (2011). Life history interview, 5 May 2011, Newcastle-upon-Tyne, UK.

Interviewee C. (2011). Life history interview, 23 September 2011, Delhi, India.

Interviewee D. (2015). Life history interview, 2 October 2015, London, UK.

Jenkins, R. (2014). Social identity. $4^{\text {th }}$ edn. London: Routledge. 
Khaire, M. and Wadhwani, R.D. (2010). Changing landscapes: The construction of meaning and value in a new market category - modern Indian art. Academy of Management Journal, 53, 1281-1304.

Kipping, M. and Üsdiken, B. (2014). History in organization and management theory: More than meets the eye. Academy of Management Annals, 8, 535-588.

Koselleck, R. (2004). Futures past: On the semantics of historical time. New York: Columbia University Press.

Kristeva, J. (1986). The Kristeva reader (Ed. T. Moi). Oxford: Blackwell.

Kroeze, R. and Keulen, S. (2013). Leading a multinational is history in practice: The use of invented traditions and narratives at AkzoNobel, Shell, Philips and ABN AMRO. Business History, 55, 1265-1287.

Lafley, A.G. and Charan, R. (2008). The game-changer: How you can drive revenue and profit growth through innovation. New York: Crown Business.

Li, Y. (2017). A semiotic theory of institutionalization. Academy of Management Review, 42, 520-547.

Maclean, M., Harvey, C. and Clegg, S.R. (2016). Conceptualizing historical organization studies. Academy of Management Review, 41, 609-632.

Maclean, M., Harvey, C. and Clegg, S.R. (2017). Organization theory in Business and Management History: Current status and future prospects. Business History Review, 91, 457-481.

Maclean, M., Harvey, C., Sillince, J.A.A. and Golant, B.D. (2014). Living up to the past? Ideological sensemaking in organizational transition. Organization, 21, 543-567.

Maclean, M., Harvey, C., Suddaby, R. and O'Gorman, K. (2017). Political ideology and the discursive construction of the multinational hotel industry. Human Relations, forthcoming. DOI: 10.1177/0018726717718919.

March, J.G. (1996). Continuity and change in theories of organizational action. Administrative Science Quarterly, 41, 278-287.

Miles, M.B. and Huberman, A.M. (1994). Qualitative data analysis: An expanded sourcebook $2^{\text {nd }}$ edn. Thousand Oaks, CA: Sage.

Mordhorst, M. (2014). Arla and Danish national identity - business history as cultural history. Business History, 56, 116-133.

O'Connor, E. (2002). Storied business: Typology, intertextuality, and traffic in entrepreneurial narrative. Journal of Business Communication, 39, 36-54. 
P\&GCA [Procter \& Gamble Corporate Archive, Cincinnati] (1937). EXS [Executive speech series.]: R.R. Deupree, 'Men make a business', Moonbeams, 1937 [reprinted from Moonbeams, 1931].

P\&GCA (1947). EXS: R.R. Deupree, 'Teamwork in our business', March 1947.

P\&GCA (1948). EXS: R.R. Deupree, 'Management's responsibilities to employees', 12 June 1948.

P\&GCA (c.1957). EXS: N. McElroy, Extracts of speeches on communication, undated.

P\&GCA (1960). EXS: W.L. [Jake] Lingle, 'The character of the company', 15 December 1960.

P\&GCA (1962). EXS: N. McElroy, 'Excerpts from year-end management talks by Neil McElroy'.

P\&GCA (1973). EXS: H. Morgens, 'Excerpts from Howard Morgens' year-end management dinner talks, 1-13.

P\&GCA (1976). ARA [Annual Reports and Accounts series]: special feature on history and values, 'Procter \& Gamble - A company built on individual freedom and initiative', 8-14.

P\&GCA (1981). EXS: E.G. Harness, 'Address to P\&G management', 21-32.

P\&GCA (1982). A statement of purpose. Fact Sheet, 1 September 1982.

P\&GCA (1987). ARA: celebrating 150 years of excellence, 1-52.

P\&GCA (1988a). EXS: J.G. Smale, 'Worldwide management meeting', 18 April 1988.

P\&GCA (1988b). ARA: J.G. Smale, 'President's report to shareholders for year ended 30 June 1988'.

P\&GCA (1991a). ARA, 1-36.

P\&GCA (1991b). EXS: E.L. Artzt, 'Gaining a competitive edge', 15 October 1991.

P\&GCA (1993). W.L. Lingle. Oral history interview, conducted c. 1993.

P\&GCA (1994a). EXS: E.L. Artzt, 'Unchanging values in changing times', November 1993, reproduced in $P \& G$ World, January-March 1994, 12-15.

P\&GCA (1994b). O.B. Butler. Oral history interview, 26-27 September 1994.

P\&GCA (1994c). D.P. Fite. Oral history interview, 15 June 1994.

P\&GCA (1994d). T.C. Bower. Oral history interview, 2 November 1994. 
P\&GCA (1994e). EXS: H. Einsmann, 'Europe 1993-94 H. Einsmann management address', 4 November 1994.

P\&GCA (1995). EXS: J.E. Pepper, ‘Keys to P\&G’s success’, 21 March 1995.

P\&GCA (1996). EXS: J.E. Pepper, 'P\&G: a personal perspective', 30 May 1996.

P\&GCA (2000). EXS: A.G. Lafley. '10 things I believe', AG Online, 11 July 2000.

P\&GCA (2001). EXS: J.E. Pepper, ‘GLBC conference call’, 21 March 2001.

P\&GCA (2002). ARA: A.G. Lafley, Financial review, 5 August 2002.

P\&GCA (2003). EXS: J.E. Pepper, 'P\&G - more than a company: An institution and community’, 2003 P\&G alumni meeting, Cincinnati, undated.

P\&GCA (2005). EXS: A.G. Lafley, 'The quiet transformation of P\&G', 25 June 2005.

Pepper, J. (2005). What really matters: Reflections on my career at Procter \& Gamble with guiding principles for success in the marketplace and in life. Cincinnati: P\&G.

Phillips, N., Lawrence, T.B. and Hardy, C. (2004). Discourse and institutions. Academy of Management Review, 29, 635-652.

Popp, A. and Holt, R. (2013a). The presence of entrepreneurial opportunity. Business History, 55, 9-28.

Popp, A. and Holt, R. (2013b). Entrepreneurship and being: The case of the Shaws. Entrepreneurship \& Regional Development, 25, 52-68.

Porter, J.E. (1986). Intertextuality and the discourse community. Rhetoric Review, 5, 34-47.

Raff, D.M.G. (2013). How to do things with time. Enterprise and Society, 14, 435-466

Rojas, F. (2010). Power through institutional work: Acquiring academic authority in the 1968 Third World strike. Academy of Management Journal, 53, 1263-1280.

Rowlinson, M. and Hassard, J. (1993). The invention of corporate culture: A history of the histories of Cadbury. Human Relations, 46, 299-326.

Rowlinson, M., Hassard, J. and Decker, S. (2014). Strategies for organizational history: A dialogue between historical theory and organization theory. Academy of Management Review, 39, 250-274.

Saussure, F. de (1974). Course in general linguistics. London: Fontana.

Selznick, P. (1949). TVA and the grass roots: A study of politics and organization. Quid Pro Books: New Orleans, LA. 
Selznick, P. (1957). Leadership in administration: A sociological interpretation. Berkeley and Los Angeles: University of California Press.

Suddaby, R., Elsbach, K.D., Greenwood, R., Meyer, J.W. and Zilber, T.B. (2010a). Organizations and their institutional environments - Bringing meaning, values, and culture back in: Introduction to the special research forum. Academy of Management Journal, 53, 1234-1240.

Suddaby, R., Foster, W.M. and Mills, A.J. (2014). Historical institutionalism. In M. Bucheli \& R.D. Wadhwani (Eds.), Organizations in time: History, theory, methods: 100-123. Oxford: OUP.

Suddaby, R., Foster, W.M. and Quinn-Trank, C. (2010b). Rhetorical history as a source of competitive advantage. In J.A.C. Baum and J. Lampel (Eds.), Globalization of strategy research, 27, 147-173. London: Emerald.

Suddaby, R., Foster, W.M. and Quinn-Trank, C. (2016). Organizational re-membering: Rhetorical history as identity work. In The Oxford Handbook of Organizational Identity, 297-316, Oxford: OUP.

Vaara, E. and Monin, P. (2010). A recursive perspective on discursive legitimation and organizational action in mergers and acquisitions. Organization Science, 21, 3-22.

Van Maanen, J. (1978). People processing: Strategies of organizational socialization. Organizational Dynamics, 7, 19-36.

Wadhwani, R.D. and Bucheli, M. (2014). The future of the past in management and organization studies. In In M. Bucheli and R.D. Wadhwani (Eds.), Organizations in time: History, theory, methods: 3-30. Oxford: OUP.

Wadhwani, R.D. and Jones, G. (2014). Schumpeter's plea: Historical reasoning in entrepreneurship theory and research. In M. Bucheli and R.D. Wadhwani (Eds.), Organizations in time: History, theory, methods: 192-216. Oxford: OUP.

Weick, K.E. (1995). Sensemaking in organizations. Thousand Oaks, CA: Sage. 
Table 1: Procter \& Gamble Average Annual Sales and Earnings by Strategic Era*

\begin{tabular}{|l|r|r|r|r|c|}
\hline & & $\begin{array}{l}\text { Profit } \\
\text { Before Tax } \\
\text { (PBT) } \\
\text { Sales } \\
\text { Strategic Eras }\end{array}$ & $\begin{array}{l}\text { PBT as } \\
\text { \% of } \\
\text { Sallion }\end{array}$ & $\begin{array}{l}\text { \% Sales } \\
\text { Outside } \\
\text { US }\end{array}$ & $\begin{array}{l}\text { Profit } \\
\text { After Tax } \\
\text { from } \\
\text { Outside } \\
\text { US }\end{array}$ \\
\hline $1970-1974$ & $3,698.1$ & 506.9 & 13.7 & 31.1 & 24.8 \\
\hline $1975-1979$ & $7,461.5$ & 837.8 & 11.2 & 29.7 & 19.6 \\
\hline $1980-1984$ & $11,916.0$ & $1,325.1$ & 11.1 & 30.0 & 15.8 \\
\hline $1984-1989$ & $17,345.0$ & $1,273.0$ & 7.3 & 33.3 & 25.3 \\
\hline Pre-Global Era & $\mathbf{1 0 , 1 0 5 . 2}$ & $\mathbf{9 8 5 . 7}$ & $\mathbf{1 0 . 8}$ & $\mathbf{3 1 . 0}$ & $\mathbf{2 1 . 4}$ \\
\hline $1990-1994$ & $28,351.8$ & $2,337.6$ & 8.2 & 47.2 & 28.4 \\
\hline $1995-1999$ & $35,952.2$ & $5,092.8$ & 14.2 & 49.9 & 37.2 \\
\hline $2000-2004$ & $42,843.4$ & $6,683.0$ & 15.6 & n.a. & n.a. \\
\hline $2004-2009$ & $72,794.2$ & $13,793.0$ & 18.9 & 52.6 & n.a. \\
\hline Post-Global Era & $\mathbf{4 4 , 9 8 4 5 . 4}$ & $\mathbf{6 , 9 7 6 . 6}$ & $\mathbf{1 4 . 2}$ & - & - \\
\hline
\end{tabular}

*Computed from data extracted from P\&G annual reports and accounts, 1970-2009. After 2000 , data on overseas operations previously recorded in various notes to the accounts are no longer reported consistently as the emphasis shifts to reporting by global product classes.

\section{Table 2: Data, themes and uses of the past}

\begin{tabular}{|c|c|c|}
\hline $\begin{array}{l}\text { Illustrative } 1^{\text {st }} \text { order quotes from two strategic eras: (1) 1950- } \\
\text { 89, and (2) 1990-present }\end{array}$ & $\begin{array}{l}2^{\text {nd }} \text { order } \\
\text { themes }\end{array}$ & $\begin{array}{l}\text { Uses of } \\
\text { the past }\end{array}$ \\
\hline $\begin{array}{l}\text { 1. 'To get and keep good men, we must be able to offer not only reasonable salaries ... } \\
\text { but also other plans helpful to them in [retirement] ... and there must be an } \\
\text { atmosphere in which people live in harmony, with the opportunity of accomplishing } \\
\text { the maximum in line with their capabilities.' Neil McElroy, Shareholder's Letter, } 1954 . \\
\text { 2. 'Recruiting, developing and retaining the best people will be a major priority for all } \\
\text { P\&G managers so we can meet growth projections in the coming decade. Because we } \\
\text { are a promotion-from-within company, the future quality of the organization } \\
\text { depends on the people we recruit.' Edwin Artzt, Shareholder's Letter, 1991. }\end{array}$ & $\begin{array}{l}\text { P\&G regards } \\
\text { its employees } \\
\text { as its greatest } \\
\text { asset }\end{array}$ & \multirow{3}{*}{$\begin{array}{l}\text { Socializing } \\
\text { employees }\end{array}$} \\
\hline $\begin{array}{l}\text { 1. 'The outstanding characteristic of [P\&G] is that it has character. Its founders ... were } \\
\text { men of great character. The essence of their character has been nourished and } \\
\text { maintained ... It has made the company great. It is your job ... to perpetuate it for } \\
\text { future generations.' Walter Lingle, speech, Management Group, } 1960 \text {. } \\
\text { 2. 'P\&G has been built on the character of its people. That character is reflected in the } \\
\text { company's values, which have been fundamental to our success for more than } 160 \\
\text { years.' Document, Our Values and Policies, } 1996 \text {. }\end{array}$ & $\begin{array}{l}\text { P\&G has a } \\
\text { special } \\
\text { character and } \\
\text { culture }\end{array}$ & \\
\hline $\begin{array}{l}\text { 1. '[P\&G] is a sound, strong unit in our society ... We create products that add to the } \\
\text { cleanliness, health and well-being of people everywhere. We provide opportunities } \\
\text { for individuals and their families. And we believe that in a small way we help to } \\
\text { provide stability in this troubled world.' John Smale, Shareholder's Letter, } 1970 . \\
\text { 2. 'We are committed to improving the quality of life for consumers around the world. } \\
\text { In fact, we want to come through for people when they need help caring for } \\
\text { themselves, their families and their homes.' Alan Lafley, Shareholder's Letter, } 2001 \text {. }\end{array}$ & $\begin{array}{l}P \& G \text { is a force } \\
\text { for good in } \\
\text { society }\end{array}$ & \\
\hline $\begin{array}{l}\text { 1. 'The founding partners had ... highly developed ethical values, and they were people- } \\
\text { oriented in everything they did; their products had to be good, available at fair prices, } \\
\text { and there should be no shortcuts on quality.' Annual Report, } 1976 . \\
\text { 2. 'Even in the midst of dramatic change, some things remain the same: our core values } \\
\text { of integrity, leadership, respect for our people; our commitment to serving } \\
\text { consumers by improving their everyday lives through our products.' Durk Jager, } \\
\text { Shareholder's Letter, } 1999 \text {. }\end{array}$ & $\begin{array}{l}\text { P\&G will } \\
\text { change } \\
\text { anything } \\
\text { other than its } \\
\text { values }\end{array}$ & $\begin{array}{l}\text { Inventing } \\
\text { tradition }\end{array}$ \\
\hline
\end{tabular}


1. 'This is a creative Company, an innovation-minded Company. We have always gone ahead by creating our own growth opportunities - by developing our own new products, by developing our own new markets, and by developing performance value in our existing brands. This is our history. And the future.' Howard Morgens, speech, Management Dinner, 1965.

2. 'Innovation is at the heart of P\&G's business model. It is the primary way we delight consumers, create value with retail partners, and create new business models to deliver consistent, sustainable growth at or ahead of the Company's goals.' Annual Report, 2008.

1. 'The history of [P\&G] exemplifies the advantages of stability and continuity in fundamental policies ... of running the business for ... Its shareholders, of course, but also its employees, the communities in which it operates, and indeed our society as a whole.' John Smale, Address to Shareholders, 1987.

2. 'P\&G is more than just a great company. It is, in fact, a great institution. There is a difference between the two and it lies in the organization's ability to sustain its greatness.' John Pepper, Address to Shareholders, 1998.

1. 'There is a conventional wisdom that brands ... grow old with time and pass away. This need not be true ... We expect each of our brands to be administered ... with the intelligence and aggressiveness needed to maintain attractiveness to consumers indefinitely.' John Smale, speech, Management Group, 1977.

2. 'P\&G's globalization today mirrors Europeanization in the 1970 s... It wasn't easy, but when all our European operations joined forces, we found that we were able to compete much better.' Jurgen Hintz, cited in Annual Report, 1990.

1. 'No single brand in [P\&G's] product family better exemplifies the guiding principles behind the Company's success than Ivory ... [we] developed a product that met a need, it performed well and was fairly priced.' Annual Report, 1979.

2. 'In the 15 years between WWII and 1960 we introduced well over a dozen major new brands ... like Tide, Crest, Head \& Shoulders, Pampers ... [It] changed our Company's fortunes. By the early 1960s we were nearly five times the size.' Wolfgang Berndt, speech, American Marketing Association Doctoral Symposium, 1997.

1. 'Right from the start William Procter and James Gamble realized that the interests of the organization and its employees were inseparable, and the partners saw to it that that belief was transmitted to their successors.' Richard Deupree,, 1955, cited in Annual Report 1976.

2. 'A number of times over these past five years, I've thought about the responsibility we have as stewards of $P \& G$, the institution. In particular, I've reflected on the thoughts of CEOs who came before me.' Alan Lafley, speech, The Quiet Transformation of P\&G, P\&G Alumni, 2005. 